\title{
KEARIFAN LOKAL MASYARAKAT ADAT DAYAK HIBUN DALAM MELESTARIKAN HUTAN TERINGKANG DI DUSUN BERUAK DESA GUNAM KECAMATAN PARINDU KABUPATEN SANGGAU
}

(Dayak Hibun Local Wisdom in Preservation of Teringkang Forest in Beruak Gunam Village, Parindu Subdistrict, Sanggau Regency)

\author{
Sely Indri Prameswari, Iskandar AM, Slamet Rifanjani \\ Fakultas Kehutanan Universitas Tanjungpura, Jalan Imam Bonjol Pontianak, 78124 \\ E-mail: selyindri12@gmail.com
}

\begin{abstract}
Dayak hibun people cannot be separated from the forest in their daily lives. they maintain the preservation of the surrounding forest, one of which is the caged forest. The research aimed to collect information regardingthe local wisdomPublicDayak Hibun in Beruak, Gunam Village, Parindu Subdistrict, Sanggau Regency, in an effort to preserve the teringkang forest. The research method using survey method, and the technique of data collection was snowball sampling. The data was obtained through a depth-interview and interview guideline as a reference. The results of the data analysis show that there are several forms of local wisdom practiced in gunam village, namely 1. (a) prohibition of cutting down the trees, (b) opening the Teringkang forest for farming, (c) burning goods such as shrimp paste and fish, (d) taking and killing animals, (e) urinating and defecating in the Teringkang Forest, 2. belief in the presence of Bunyik (ghosts), having rituals entering the Teringkang Forest, and Keeping words politeness, 3. Hence the community has belief in mystical matters, 4. Therefore, the Teringkang Forest is still preserved up until today.
\end{abstract}

Keywords: Dayak Hibun, Local Wisdom, Teringkang Forest

\section{PENDAHULUAN}

Kearifan lokal merupakan sebuah sistem dalam tatanan kehidupan sosial, politik, budaya,ekonomi, serta lingkungan yang hidup di tengah-tengah masyarakat lokal. Ciri yang melekat dalam kearifan tradisional adalah sifatnya yang dinamis, berkelanjutan dan dapat diterima oleh komunitasnya. Dalam komunitas masyarakat lokal, kearifan tradisional terwujud dalam bentuk seperangkat aturan, pengetahuan,dan juga keterampilan serta tata nilai dan etika yang mengatur tatanan sosial komunitas yang terus hidup dan berkembang dari generasi ke generasi. Menurut Sufia dkk (2016) kearifan lokal merupakan bagian dari masyarakat untuk bertahan hidup sesuai dengan kondisi lingkungan, sesuai dengan kebutuhan, dan kepercayaan yang telah berakar dan sulit untuk dihilangkan. Kearifan lokal merupakan pengetahuan lokal yang digunakan oleh masyarakat untuk bertahan hidup dalam suatu lingkungan yang menyatu dengan sistem kepercayaan, norma, budaya dan diekspresikan dalam tradisi dan mitos yang dianut dalam jangka waktu yang lama. Fungsi kearifan lokal adalah sebagai berikut pertama, sebagai penanda identitas sebuah komunitas, kedua, sebagai elemen perekat (aspek kohesif) lintas warga, lintas agama dan kepercayaan. Ketiga, kearifan lokal memberikan warna kebersamaan bagi 
sebuah komunitas. Keempat, mengubah pola pikir dan hubungan timbal balik individu dan kelompok dengan meletakkannya di atas common ground/kebudayaan yang dimiliki. Kelima, mendorong terbangunnya kebersamaan, apresiasi sekaligus sebagai sebuah mekanisme bersama untuk menepis berbagai kemungkinan yang meredusir, bahkan merusak, solidaritas komunal, yang dipercayai berasal dan tumbuh di atas kesadaran bersama, dari sebuah komunitas terintegrasi. Menurut Thamrin (2013) hilangnya kearifan tradisional dipengaruhi oleh sikap masyarakat Indonesia yang belum mampu menjaga budaya, moral, dan sikap terhadap lingkungan sekitar mereka. Hal tersebut disebabkan, antara lain oleh tidak adanya penghargaan dan pengakuan terhadap nilainilai kearifan tradisional, adanya kecenderungan globalisasi dunia yang dapat menembus batas-batas negara sampai ke level komunitas suatu kampung. Pengetahuan masyarakat lokal terhadap sumberdaya alam itu membentuk kearifan terhadap pengelolaan hutan.Menurut Senoaji (2004) kearifan lokal terbentuk karena adanya hubungan antara masyarakat tradisional dengan ekosistem disekitarnya, yang memiliki sistem kepercayaan, hukum dan pranata adat, pengetahuan dan cara mengelola sumber daya alam secara lokal. Menurut Senoaji (2004) menjelaskan bahwa masyarakat lokal di beberapa daerah di Indonesia mampu untuk mengelola lingkungan dan sumberdaya alamnya. Pengetahuan masyarakat lokal terhadap sumberdaya alam itu membentuk kearifan terhadap pengelolaan hutan.Oleh karena itu perlu dilakukan penelitian tentang kearifanlokalberupa adat istiadat di Dusun Beruak Desa Gunam Kecamatan Parindu Kabupaten Sanggau. Tujuan dari penelitian ini adalah untuk mengumpulkan data mengenai kearifan lokal adat istiadat di Dusun Beruak Desa Gunam Kecamatan Parindu Kabupaten Sanggau.

METODE PENELITIAN

Penelitian dilaksanakan di Hutan Teringkang Dusun Beruak Desa Gunam Kecamatan Parindu Kabupaten Sanggaudengan waktu penelitian daritanggal 15 Agustus sampai 15September 2019. Metode penelitian menggunakan metode survey dan pengambilan sampel dilakukan menggunakan snowball sampling. Informan dalam penelitian ini adalah masyarakat di sekitar Hutan Teringkang sedangkan informan kunci dalam penelitian ini adalah Ketua Adat, Kepala Desa, Tokoh Masyarakat. Analisis data disajikan dalam bentuk deskriptif kualitatif. Analisis data kualitatif berbentuk deskriptif menurut Agusta (2003) berupa kata - kata lisan atau tulisan tentang tingkah laku manusia yang dapat diamati. Data yang dikumpulkan melalui wawancara terlebih dahulu dilakukan pengklasifikasian, diinterpretasikan, selanjutnya dilakukan pembahasan sehingga diperoleh kesimpulan sementara atas jawaban dari subjek penelitian. Analisis data mencakup penaksiran semua data yang telah dikumpulkan, melakukan pengaturan hasilhasil penelitian sedemikian rupa sehingga menjadi informasi yang jelas. 


\section{HASIL DAN PEMBAHASAN}

Hutan Adat Teringkang memiliki luas 12 ha, sudah lama ditetapkan oleh masyarakat sebagai Hutan Adat, kondisi hutan memiliki pohon yang masih alami terdapat jenis pohon Tapang (Kompassia excelsa), Meranti Batu (Shorea platyclados), Beringin (Ficus sp), Ubah (Syzygium sp), Tapah (Merrenia peltata),
Guho (Eusideroxylon SP), Kompah (Dyera costulata). Berdasarkan hasil wawancara dengan masyarakat dan observasi di lapangan, diperoleh hasil penelitian mengenai bentuk-bentuk kearifan lokal Adat Istiadat masyarakat yang berhubungan dengan upaya pelestarian Hutan Teringkang di Desa Gunam Dusun Beruak Tabel 1.

Tabel 1. Rekapitulasi Hasil Wawancara Kearifan Lokal Masyarakat Desa Gunam Dusun Beruak (Recapitulation of Local Wisdom Interview Results in Gunam Village Village in Beruak Village)

\begin{tabular}{|c|c|c|}
\hline No & Kearifan Lokal & Keterangan \\
\hline 1. a. & $\begin{array}{l}\text { Larangan Menebang Pohon di } \\
\text { Hutan Teringkang }\end{array}$ & $\begin{array}{l}\text { Larangan ini menyebabkan tidak ada } \\
\text { masyarakat yang berani menebang pohon } \\
\text { didalam Hutan Teringkang. }\end{array}$ \\
\hline b. & $\begin{array}{l}\text { Larangan membuka Hutan } \\
\text { Teringkang untuk Berladang }\end{array}$ & $\begin{array}{l}\text { Larangan ini menyebabkan masyarakat } \\
\text { takut membuka hutan untuk berladang }\end{array}$ \\
\hline c. & $\begin{array}{l}\text { Larangan membakar barang } \\
\text { seperti terasi, ikan di Hutan } \\
\text { Teringkang }\end{array}$ & $\begin{array}{l}\text { Larangan ini menyebabkan masyarakat } \\
\text { takut untuk berbuat yang macam-macam di } \\
\text { Hutan Teringkang. }\end{array}$ \\
\hline d. & $\begin{array}{llr}\text { Larangan } & \text { mengambil dan } \\
\text { membunuh } & \text { satwa di Hutan } \\
\text { Teringkang } & & \end{array}$ & $\begin{array}{l}\text { Larangan ini menyebabkan masyarakat } \\
\text { takut untuk mengambil atau membunuh } \\
\text { hewan-hewan yang ada sehingga hewan- } \\
\text { hewan tersebut masih tetap ada di Hutan } \\
\text { Teringkang. }\end{array}$ \\
\hline & $\begin{array}{l}\text { Larangan buang air kecil dan } \\
\text { besar di Hutan Teringkang }\end{array}$ & $\begin{array}{l}\text { Larangan ini menyebabkan masyarakat } \\
\text { takut untuk bersikap yang dianggap dapat } \\
\text { mengotori Hutan Teringkang. }\end{array}$ \\
\hline 2. & $\begin{array}{l}\text { Kepercayaan terhadap adanya } \\
\text { orang Bunyik (Hantu) }\end{array}$ & $\begin{array}{l}\text { Kepercayaan terhadap mitos ini } \\
\text { menyebabkan masyarakat sangat takut } \\
\text { untuk berperilaku yang dapat merusak } \\
\text { kelestarian Hutan Teringkang karena masih } \\
\text { percaya terhadap mitos orang bunyik }\end{array}$ \\
\hline 3. & $\begin{array}{l}\text { Ritual memasuki } \\
\text { Teringkang }\end{array}$ & $\begin{array}{l}\text { Acara adat ini dilakukan masyarakat } \\
\text { tujuannya untuk permisi memasuki Hutan } \\
\text { Teringkang. }\end{array}$ \\
\hline 4. & Menjaga tutur kata & $\begin{array}{l}\text { Kepercayaan ini membuat masyarakat takut } \\
\text { untuk berkata kotor karena Hutan } \\
\text { Teringkang ini dianggap mistik sehingga } \\
\text { bila ada yang melanggar akan mendapatkan } \\
\text { musibah. }\end{array}$ \\
\hline
\end{tabular}

Sumber: data hasil wawancara dan observasi lapangan di Hutan Teringkang (2019). 
Bentuk-bentuk Kearifan lokal yang saat ini masih ada dalam kehidupan masyarakat dalam upaya melestarikan Hutan Teringkang di Desa Gunam Dusun Beruak dijelaskan sebagai berikut:

\section{Larangan}

a. Larangan Menebang Pohon di Hutan Teringkang

Dari hasil wawancara yang dilakukan terhadap kearifan lokal masyarakat Desa Gunam Dusun Beruak dalam menjaga kelestarian Hutan Teringkang menerapkan aturan larangan penebangan pohon di kawasan Hutan Teringkang. Peraturan ini dibuat dan ditetapkan oleh Temenggung Kia, apabila ada yang menebang pohon di hutan adat teringkang orang yang menebang pohon tersebut bisa sakit seperti orang membakar pohon badannya bisa panas, orang yang menebang kayu bisa jadi linglung. Larangan menebang pohon di dalam Hutan Teringkang ini bertujuan untuk menjaga ekosistem yang ada di hutan yang merupakan habitat pohon-pohon seperti pohon Tapang (Kompassia excelsa), pohon Meranti Batu (Shorea platyclados), pohon Ubah (Syzygium sp), pohon Beringin (Ficus sp), pohon Tapah (Merrenia peltata), Guho (Eusideroxylon sp), Kompah (Dyera costulata), dan berbagai jenis pohon lain yang menjadi habitat bagi satwa sebagai tempat berkembang biak dan sebagai tempat mencari makan.

Dari hasil observasi dilapangan tidak ditemukan adanya penebangan pohon di dalam kawasan Hutan
Teringkang, sehingga saat ini kondisi Hutan Teringkang terjaga kelestariannya. Masyarakat sekitar hutan pun turut menjaga kelestarian hutan dengan tidak mengambil atau menebang pohon karena jika mereka melanggar hal tersebut masyarakat langsung mendapatkan sanksi dari Hutan Teringkang itu sendiri karena masyarakat menyebutkan Hutan Teringkang memiliki kepercayaan terhadap hal-hal mistik oleh karena itu Hutan Teringkang masih tetap terjaga kelestariannya hingga saat ini.Kearifan lokal masyarakat berupa adanya larangan menebang pohon di Hutan Teringkang merupakan salah satu aturan positif yang ada didalam kehidupan masyarakat Desa Gunam. Yamani(2011) mengungkapkan Materi muatan aturan lokal materil pada enam komunitas adat meliputi aturanberkenaan dengan kategori hutan yang boleh diusahakan, tabu atau laranganmenyangkut hutan, dan sanksi adat sebagai reaksi dilanggarnya aturan materil.Aturan materil pada komunitas adat satu sama lainnya menunjukkan persamaan, berkenaan dengan kategori hutan yang boleh diusahakan meliputi semua hutan,kecuali qhimbo tuo, utan tuwe, imbeh tuwe, imoh bano, gimbo gedang, imbu tuo, atau hutan tuwo. Pelaksanaan perlindungan hutan secara preventif berupa pembentukan dan pelaksanaan hukum kehutanan lokal, yang berkenaan dengan tabu atau larangan terangkum dalam istilah hukum lokal, seperti dalam aturan materil lokal dalam komunitas adat suku Serawai terdapat tabu atau 
larangan yang dalam istilah local disebut sepelansaran mayat, sepenetaan akaqh kayu, merabung bumi, tana angker, tana siboan, elang setepak, bemban teralai, macan merunggu, ulu tulung betangisan, dan ulu tulung tunggal.

Komunitas adat suku Lembak Delapan mengenal tabu atau larangan yang disebut tanjung kerapusan, suak uluh tulung; tinjau terkukuh; tanam tukuh dan aturan adat utan tiga ragi. Tabu atau larangan serupa dikenal pula dalam komunitas adat lainnya dengan sebutan yang berbeda namun memiliki makna yang sama,Materi muatan hukum kehutanan lokal materil pada enam komunitas adat secara garis besarnya mengatur perbuatan materil menyangkut hutan antara lain: 1) setiap orang dilarang menebang habis pohon dalam hutan yang berakibat terjadinya kegundulan hutan, karena dapat menimbulkan bencana. 2) setiap orang dilarang menebang pohon dalam hutan melebihi kebutuhan hidupnya. 3) setiap

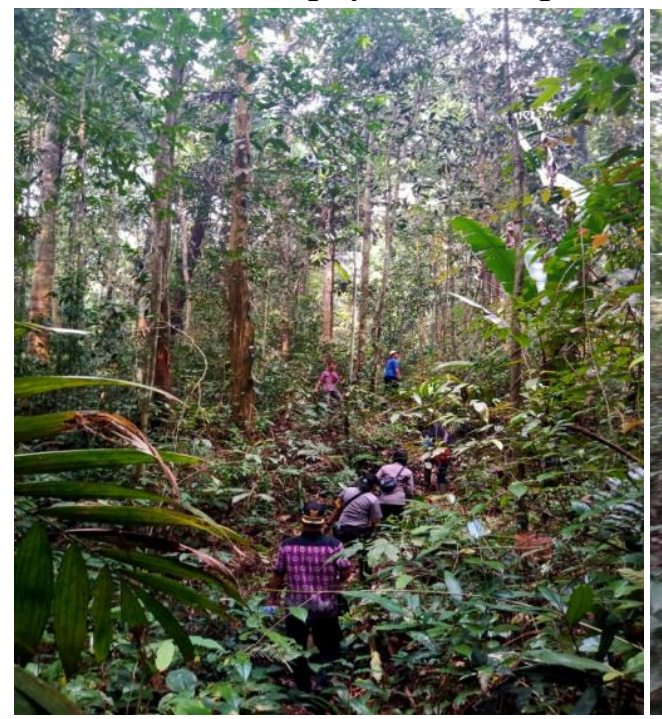

orang tidak boleh menguasai hutan, sumber air, sungai, pantai dan laut secara individual. 4) setiap orang tidak boleh membuka hutan tanpa izin penjabat marga. 5) setiap orang tidak boleh menebang pohon dalam hutan tanpa izin penjabat marga. 6) setiap orang dilarang menebang pohon yang tidak memenuhi kriteria seperti diameternya belum $50 \mathrm{~cm}$. 7) setiap orang dilarang menebang pohon di sembarang tempat, seperti di sekitar mata air. 8) setiap orang dilarang menebang pohon langka dengan fungsi pengobatan tradisional. 9) setiap orang dilarang mengambil hasil hutan, berburu, dalam kawasan hutan larangan. 10) setiap orang dilarang membuka ladang di sekitar ulu tulung, yaitu tempat sumber mata air. 11) setiap orang dilarang membuka ladang pada kontur tanah yang berbentuk cekungan (bekok), karena dapat mengakibatkan erosi atau tanah longsor. 12) setiap orang dilarang memanen madu sialang dengan menebang atau merusak pohon.

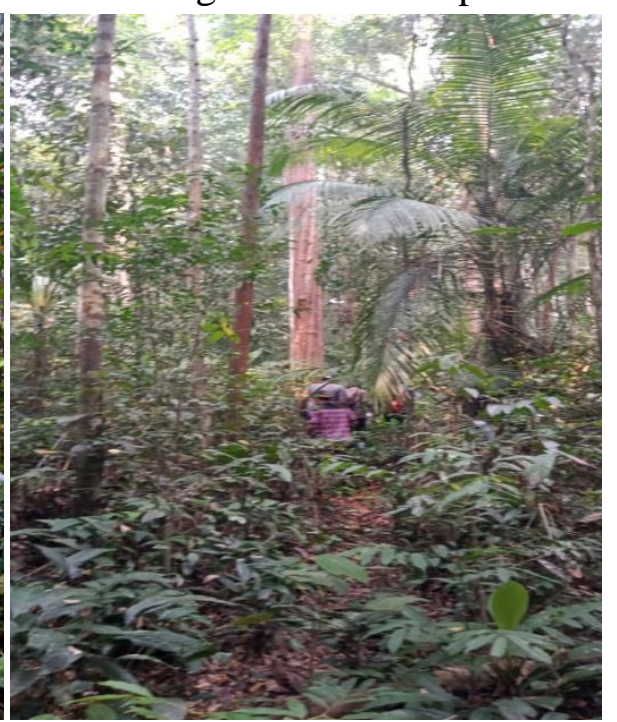

Gambar 1. kondisi pohon yang ada di dalam Hutan Teringkang di Desa Gunam Dusun Beruak (the condition of the trees that exist in the Teringkang Forest in Gunam Village in Beruak Hamlet) 


\section{b. Larangan membuka Hutan Teringkang untuk Berladang}

Berdasarkan hasil wawancara dengan masyarakat sekitar hutan diperoleh informasi adanya larangan untuk tidak membuka areal perladangan di dalam Hutan Teringkang.

Masyarakat Desa Gunam khususnya Dusun Beruak sebagian besar masyarakatnya bermata pencaharian sebagai petani atau berladang, tetapi masyarakat sangat mematuhi aturan untuk tidak membuat areal perladangan di dalam hutan teringkang karena menurut masyarakat Hutan Teringkang harus dijaga kesakralannya karena dipercaya tempat dan dihuni oleh makhluk gaib sehingga tidak boleh dirusak karena dapat mendatangkan bencana bagi masyarakat.

Sampai saat ini tidak ada masyarakat yang berani membuka Hutan Teringkang untuk berladang, tidak adanya pantauan dari kegiatan masyarakat disekitar hutan yang dapat merusak hutan karena masyarakat sudah tahu bahwa Hutan Teringkang ini tidak boleh diganggu sama sekali, jika ada masyarakat yang mengganggu pada kasus di Dusun Beruak orang meninggal, esoknya belum habis abu dari orang pertama yang meninggal ada lagi yang meninggal dari kasus tersebut hingga saat ini masyarakat sekitar Hutan Teringkang tidak berani untuk membuka hutan terebut untuk berladang, maka dari itu Hutan Teringkang hingga kini masih terjaga kelestariannya.

Menurut Sinapoy (2018) pengetahuan masyarakat adat tersebut memunculkan banyak pengetahuan dan tata nilai tradisional yang dihasilkan dari proses adaptasi dengan lingkungannya. Sesuai dengan kebutuhan dasar manusia, salah satu bentuk pengetahuan tradisional yang berkembang terkait dengan pengetahuan dalam pemanfaatan lahan, pemanfaatan alam untuk keperluan hidup sehari-haris harus dipergunakan secara arif dan bijaksana, kekayaan alam tidak untuk dihabiskan dan tidak untuk dirusak. Hal ini bermakna bahwa hubungan manusia dengan alam sangatlah dekat serta saling menjaga keseimbangan.

Pemanfaatan, penggunaan, dan pengelolaan SDA maupun kelestarian lingkungan, masyarakat adat dengan pengetahuan kearifan lokalnya (indigenous knowledge) sangat berpegang teguh pada kekuatan hukum adat, kemampuan spiritual, dan religi yang dianutnya, ternyata lebih arif dibandingkan dengan cara-cara modern yang dikembangkan oleh masyarakat modern dengan segudang pengetahuan. Pengetahuan lokal yang dikenal sebagai kearifan lokal tumbuh dan berkembang di dalam masyarakat sebagai pengetahuan yang diturunkan dari generasi ke generasi sebagai bagian dari adaptasi terhadap lingkungannya.

c. Larangan membakar barang seperti terasi, ikan di Hutan Teringkang

Masyarakat sangat mempercayai hal mistik yang ada di Hutan Teringkang bahkan di Hutan Teringkang terdapat tempat yang sangat bersih tanpa ada yang membersihkannya. Maka dari itu tempat tersebut dilarang untuk dikotori. Tempat tersebut dianggap tempat berkumpulnya mahkluk-makhluk gaib untuk menjaga Hutan Teringkang, oleh karena itu masyarakat setempat dilarang untuk 
membakar barang yang dianggap dapat mengganggu mahkluk-mahkluk gaib karena jika ada yang melanggar akan mendapatkan ganjarannya seperti menjadi linglung. Menurut Yulianto (2019) makhluk gaib diduga memiliki kesukaan terhadap benda-benda tertentu dan tempattempat tertentu, seperti makanan tertentu dan tempat tertentu. Oleh sebab itu, sebaiknya kita jangan melakukan perbuatan yang kemungkinan akan didatangi makhluk gaib.

\section{d. Larangan mengambil dan membunuh satwa di Hutan Teringkang}

Hutan Teringkang merupakan tempat hidup dan berkembangbiak dari berbagai jenis satwa seperti ular, monyet, dan lainnya masyarakat melarang untuk membunuh satwa tersebut karena hal tersebut dianggap dapat mempengaruhi kestabilan ekosistem di Hutan Teringkang.Satwa yang ada di hutan dapat membantu tumbuhan dalam penyerbukan bunga dan membantu penyebaran biji-biji tumbuhan. Berkat adanya larangan tersebut diharapkan satwa-satwa yang ada di hutan akan tetap ada keberadaannya, jika keberadaan satwa tetap terjaga maka kelestarian Hutan Teringkang akan tetap lestari.

Menurut Prabowo dkk (2017) sebagai salah satu komponen ekosistem, jenis-jenis satwa liar sebagai individu atau kelompok mempunyai peran dalam menjaga keseimbangan proses dialam. Secara umum, beberapa jenis satwa liar merupakan konsumen pertama dalam piramida makanan, sedangkan beberapa jenis satwa liar merupakan konsumen kedua, ketiga dan seterusnya. Dengan demikian kelangsungan kehidupan satwa akan tergantung satu sama lain dan penurunan populasi salah satu diantaranya akan berdampak negatif terhadap kesinambungan jaring-jaring makanan dan menghambat kelancaran arus dan siklus energi. Terlihat bahwa ketiadaan salah satu jenis diantara satwa akan merupakan pemicu masalah secara ekologis.

Upaya perlindungan terhadap satwa dan hidupan liar di Indonesia mengacu pada UU No 5 Tahun 1990 tentang konservasi sumberdaya alam hayati dan ekosistemnya. Perlindungan dilakukan terhadap kawasan sebagai habitat serta terhadap jenis satwa.Perlindungan habitat berarti melindungi kawasan secara keseluruhan, sehingga semua jenis tumbuhan atau satwa yang hidup di kawasan tersebut dilindungi secara hukum.

Status perlindungan satwa dan hidupan liar lainnya, tidak hanya berdasarkan hukum nasional, tetapi juga kesepakatan internasional, baik berdasarkan keterancaman populasinya oleh IUCN (International Union for Conservation of Nature), maupun berdasarkan kesepakatan perdagangan antar Negara oleh CITES (The Convention on International Trade in Endangered Species). Ketentuan IUCN maupun CITES juga berlaku bagi Indonesia karena Indonesia telah meratifikasi kesepakatan tersebut.

\section{e. Larangan buang air kecil dan besar di} Hutan Teringkang

Masyarakat bahwa masyarakat sangat mempercayai hal mistik yang ada di Hutan Teringkang bahwa hutan tersebut tidak boleh dikotori adapun pantangannya jika 
ada orang yang buang air kecil maupun buang air besar di Hutan Teringkang maka orang tersebut akan mendapatkan sakit seperti tidak bisa buang air kecil begitu juga jika orang buang air besar sembarangan maka akan mendapat sakit tidak bisa buang air besar. Masyarakat sangat meyakini hal tersebut sehingga Hutan Teringkang hingga saat ini dapat terjaga kebersihan dan kelestariannya.

Menurut Yulianto (2019) Salah satu penjaga nilai-nilai, norma, dan etika tersebut adalah pemali. Pemali masyarakat Banjar dapat mengetahui mana yang boleh dan tidak boleh dilakukan. Pendidikan melalui pemali ini dirasa tidak terlalu menggurui, tetapi sangat efektif. Hal itu disebabkan pemali hanya terdiri atas beberapa kata saja, tetapi memiliki aspek persanksian di dalamnya. Aspek persanksian itulah yang membuat pemali menjadi begitu diperhitungkan di tengah masyarakat Banjar. Masyarakat Banjar adalah masyarakat yang religius yang memercayai adanya alam gaib dan memiliki kepercayaan agama. Pemali menjadikan masyarakat Banjar menjadi lebih arif dalam menyikapi keduanya. Pemali merupakan kejeniusan lokal dalam membentuk dan mendidik masyarakat.

Masyarakat mempunyai mekanisme khusus untuk dapat menilai seseorang itu baik atau tidak. Mekanisme ini mengajarkan bahwa orang yang taat terhadap pemali yang terdapat dalam masyarakatnya itulah orang yang baik dan mengetahui norma-norma. Orang yang tidak memedulikan pemali adalah orang yang dianggap kurang baik dan kurang mengetahui adat di dalam masyarakatnya.
Pemali dalam masyarakat Banjar adalah sebagai sarana pendidikan norma, nilai, dan etika di tengahmasyarakatnya. Pendidikan tersebut menjadi begitu efektif disebabkan terdapat aspek persanksian dan juga tidak bersifat menggurui.

\section{Kepercayaan terhadap adanya orang Bunyik (Hantu)}

Masyarakat percaya adanya hal mistik seperti orang bunyik (hantu) yang menjadi penunggu Hutan Teringkang. Orang bunyik ini dipercaya akan menyesatkan orang yang tidak dikenal atau orang baru yang memasuki kawasan Hutan Teringkang. Orang bunyik juga dipercaya dapat memberikan berita jika ada sesuatu yang tidak baik di kampung Beruak yaitu berita adanya orang meninggal di kampung Beruak dengan diberi tanda seperti orang karaoke ataupun seperti bunyi ronggeng dan bunyi suara binatang kelempiau dari dalam Hutan Teringkang.

Kepercayaan terhadap orang bunyik yang secara turun temurun diwariskan memberikan hal positif terhadap Hutan Teringkang. Kepercayaan ini membuat masyarakat tidak berani merusak ekosistem hutan karena dipercaya jika kita merusak hutan maka orang bunyik akan marah dan memberikan bencana. Orang bunyik dipercaya sebagai penjaga hutan, dari kepercayaan dan mitos yang turun temurun diwariskan masyarakat Desa Gunam Dusun Beruak kepada generasinya, sehingga sampai saat ini Hutan Teringkang tetap dianggap sakral oleh masyarakat dan tetap terjaga kelestarian ekosistemnya.

Warisan kebudayaan yang berupa warisan moral-spiritual, satu di antaranya didapatkan dan diketahui melalui tradisi 
keyakinan atau kepercayaan suatu masyarakat. Hasanuddin, W. S. (2015) menyatakan nilai-nilai budaya tradisi sebagai suatu tipe pengucapan merupakan suatu sistem dalam berkomunikasi. Kehidupan manusia dan dengan sendirinya hubungan antar manusia dikuasai atas keyakinan-keyakinan atau kepercayaankepercayaan. Jika tumbuh dan berkembang, keyakinan atau kepercayaan diterima sebagai kebenaran. Keyakinan masyarakat akan sesuatu hal mungkin saja melewati batas logika umum.

Keyakinan yang semacam itu menurut Hasanuddin, W. S. (2015) tidak dapat dipersalahkan. Hal yang harus diperhatikan dari keyakinan masyarakat bukanlah persoalan benar atau tidak benar, melainkan sejauh mana hal tersebut berfungsi di dalam memenuhi fungsifungsi sosial kehidupan masyarakat tersebut. Oleh sebab itu, pada kondisi dimana masyarakat mempercayai suatu nilai-nilai tradisi sebagai suatu kebenaran dan hal yang diyakini itu memungkinkan munculnya solidaritas komunal, maka keyakinan semacam itu dapat berfungsi sebagai dalil sebagaimana ilmu pengetahuan, aturan yang diwariskan dan diamalkan pergenerasi merupakan suatu bentuk ingatan dan kenangan, ide, ataupun keputusan yang diyakini di dalam kondisi yang benar dan konstruktif.

Menurut Hasanuddin, W. S. (2015)Nilai-nilai tradisi dapat membantu dinamika kehidupan masyarakat tempat nilai-nilai mendasar itu hidup dan berkembang menumbuhkan dan mengembangkan integritas masyarakat, menciptakan solidaritas sosial, menumbuhkan kebanggaan akan identitas kelompok, dan berguna pula untuk mengukuhkan keharmonisan komunal. Oleh sebab itu, pada hakikatnya setiap masyarakat, baik masyarakat tradisional maupun masyarakat modern memerlukan nilai-nilai kehidupan yang didasari atas keyakinan atau kepercayaan atas hal-hal tertentu untuk menjalani perikehidupan bersama yang harmonis.

\section{Ritual memasuki Hutan Teringkang}

Ritual adat memasuki Hutan Teringkang merupakan kegiatan yang dilakukan sebelum memasuki hutan oleh masyarakat di Desa Gunam maupun luar Desa Gunam. Ritual adat bertujuan untuk meminta izin kepada makhluk gaib agar kegiatan yang dilakukan untuk memasuki Hutan Teringkang tidak ada gangguan dan halangan atau musibah. Kegiatan ritual memasuki Hutan Teringkang oleh masyarakat Desa Gunam dengan langkahlangkah sebagai berikut:

a. Masyarakat khususnya pak Binus memberikan informasi terlebih dahulu kepada orang-orang yang akan memasuki Hutan Teringkang untuk tidak membuang air kecil di dalam Hutan Teringkang.

b. Masyarakat berkumpul di sekitar tepi Hutan Teringkang untuk menyiapkan bahan-bahan yang akan dilakukan untuk ritual bahan-bahan yang disiapkan itu seperti:

- Lump (rokok dari daun nipah)

- Kapur sirih

- Daun sirih

- Tuak

c. Setelah bahan disiapkan masyarakat membaca mantra atau doa agar penjaga 
Hutan Teringkang dapat memberikan izin, kelancaran serta kemudahan melakukan kegiatan di dalam hutan kemudian masyarakat membaca mantra atau doa sambil membakar rokok khusus kemudian membaca mantra atau doa untuk tuak kemudian tuak di siram

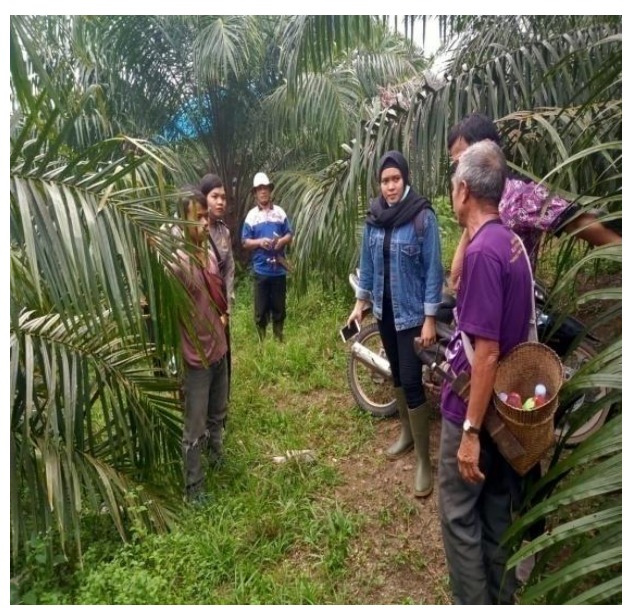

a

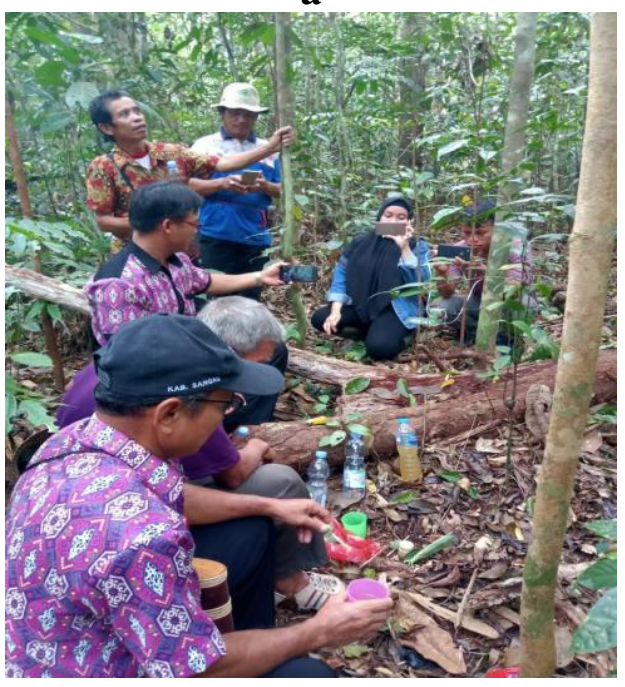

c di pinggiran Hutan Teringkang dan sisa dari tuak yang ada di minum oleh masyarakat atau orang yang akan memasuki Hutan Teringkang tuak yang ada harus dibagi rata semua kepada orang yang akan masuk dan harus dihabiskan jangan sampai ada sisa.

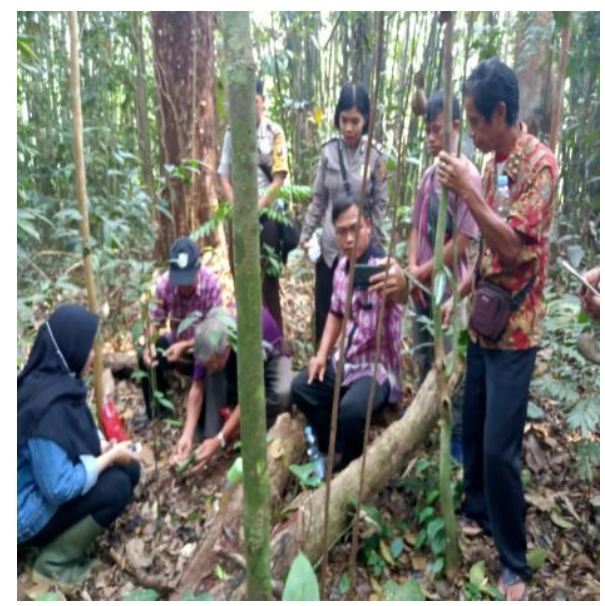

b

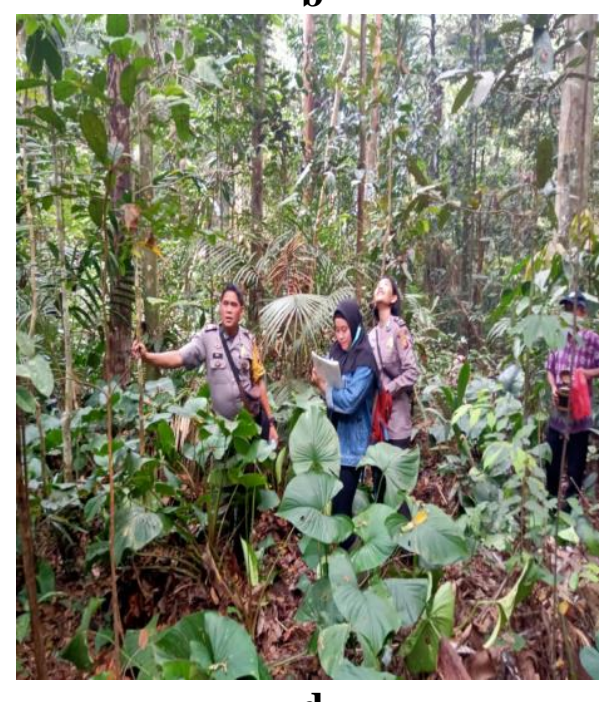

d

Gambar 2. Ritual memasuki Hutan Teringkang (The ritual enters the Teringkang Forest) Keterangan:
a. Memberikan pengarahan sebelum memasuki Hutan Teringkang oleh masyarakat Desa Gunam Dusun Beruak.
b. Masyarakat menyiapkan bahan-bahan untuk ritual di Hutan Teringkang Desa Gunam Dusun Beruak.
c. Membaca doaritual untuk memasuki Hutan Teringkang di Desa Gunam Dusun Beruak.
d. Memasuki Hutan Teringkang Desa Gunam Dusun Beruak. 
Menurut Hartono\& Setiana (2012) Tradisi penting untuk dilestarikan dengan mengupayakan pelestariannya dalam dua faktor yaitu faktor intern menekankan pelestarian dalam masyarakat karena takut bila tradisi tidak dijalankan berdampak buruk bagi mereka, dan faktor ekstern terutama lembaga pemerintah daerah dalam mendukung kegiatan melestarikan budaya lokal.Makna upacara ini dilaksanakan sebagai tonggak utama menghargai peninggalan leluhur yang masih bertahan. Pelaksanaan prosesi tidak terlepas dari segi religi atau kepercayaan asli. Syair adat dan upacara penyajian kepada roh-roh halus difungsikan sebagai naluri manusia dalam penerapan kepercayaan.

\section{Menjaga tutur kata}

Masyarakat sangat mempercayai nilai religius yang berlaku secara turuntemurun di Desa Gunam Dusun Beruak sebagai tradisi adat istiadat bagi suku dayak sebagai suku mayoritas masyarakat Desa Gunam .

Kepercayaan religius ini diterapkan dalam menjaga kelestarian Hutan Teringkang dilakukan dalam bentuk adat istiadat dan norma yang tidak tertulis namun diwarisi secara turun-temurun kepada generasinya yaitu adanya larangan berucap kata-kata kotor dan tidak sopan ketika memasuki kwasan hutan. Masyarakat percaya bahwa hutan adat ini dianggap sakral sehingga jika hal tersebut dilakukan akan mendapatkan bencana karena dianggap tidak menghormati penjaga hutan atau hantu bunyek yang turut menjaga kelestarian hutan.

Menurut Andheska(2018)ungkapan kepercayaan rakyat merupakan bagian dari tradisi masyarakat yang penyebarannya dilakukan secara lisan. Ungkapan kepercayaan rakyat ini telah dikenal oleh masyarakat secara turun temurun sehingga tidak dikenal lagi siapa yang menciptakannya. Ungkapan tersebut disampaikan secara lisan pada situasi dan konteks tertentu. Oleh sebab itu, dapat dikatakan bahwa kepercayaan rakyat merupakan semacam ungkapan tradisional daerah-daerah yang termasuk ke dalam folklor. Ungkapan kepercayaan rakyat merupakan aset kebudayaan nasional yang tersimpan dalam kebudayaan daerah.

Ungkapan mencerminkan sesuatu nilai-nilai budaya yang dianut atau yang diemban oleh pendukung daerah tersebut. Ungkapan yang disampaikan tersebut secara lisan dalam bentuk santun yang telah dibuat dan diatur oleh masyarakat penuturnya. Dapat dikatakan bahwa sebagian besar ungkapan kepercayaan rakyat yang ditemukan di Desa Gunam merupakan ungkapan yang bersifat larangan. Ungkapan larangan ini mempunyai keunikan tersendiri. Seseorang takut untuk melanggar ungkapan larangan tersebut. Apabila larangan itu dilanggar maka masyarakat percaya bahwa yang ditakutinya tersebut akan mendapatkan akibatnya.

Menurut hasil penelitian bahwa kearifan lokal yang terdapat di Hutan Adat Teringkang seperti larangan menebang pohon, larangan membuka 
Hutan Teringkang untuk berladang, larangan membakar terasi dan ikan, larangan mengambil dan membunuh satwa, larangan membuang air kecil dan besar, kepercayaan terhadap adanya orang bunyik (hantu), ritual memasuki Hutan Teringkang, dan menjaga tutur kata merupakan hal-hal yang berlaku pada masyarakat Dayak Hibun yang berhubungan dengan Hutan Teringkang,sehingga masyarakat menganggapnya suatu yang sakral dan wajib dikerjakan. Kondisi ini menyebabkan hutan teringkang tetap lestari.

Nilai-nilai kepercayaan yang berkembang melalui lisan dan foklor adalah sebagai modal yang dimiliki oleh masyarakat Hutan Teringkang dalam tercapainya kelestarian dalam menjaga Hutan Teringkang.Informasi yang mereka yakini dari leluhur penting bagi kehidupan mereka berupa mitologi yang terbangun. Mitologi tidak hanya sekedar mitos, akan tetapi penopang keberlangsungan kehidupan mereka bersama alam sekitar. Hubungan masyarakat dengan hutan tidak hanya sekedar relasi sosial biasa, akan tetapi relasi sosial yang bertujuan untuk mencapai kepentingan berupa menjaga kelestarian Hutan Teringkang.

Menurut Nurcahyono \& Astutik (2018) modal sosial merupakan suatu konsep sosiologi, yang telah digunakan dalam menganalisis berbagai macam fakta dan fenomena sosial. Modal sosial mengandung beberapa komponen antara lain kepercayaan, kewajiban danharapan (ekspektasi), norma yang menopang serta sanksi dan putaran informasi.Menurut Azwir dkk (2017) Keterlibatan masyarakat secara langsung dengan mengaitkan peran masyarakat adat mempunyai nilai edukasi yang baik dalam budaya dan hukum yang berlaku secara sah. Dalam hal ini diperlukan pula pendekatan kultural, agama yang memungkinkan keterlibatan masyarakat lokal dalam segala aktifitas.

\section{KESIMPULAN}

Berdasarkan hasil penelitian terdapat 4 bentuk kearifan lokal adat istiadat masyarakat Desa Gunam dalam menjaga kelestarian Hutan Teringkang yaitu berupa larangan, kepercayaan, ritual dan menjaga tutur kata. Larangan dapat berupa larangan menebang pohon di Hutan Teringkang, larangan membuka Hutan Teringkang untuk berladang, larangan membakar barang seperti terasi dan ikan di Hutan Teringkang, larangan mengambil dan membunuh satwa di Hutan Teringkang, larangan buang air kecil dan besar di Hutan Teringkang adanya kearifan lokal ini menyebabkan terjaganya kelestarian Hutan Teringkang

\section{SARAN}

1. Perlu studi lanjut tentang kearifan lokal masyarakat berupa nilai, norma, etika, kepercayaan dan hukum adat agar pengetahuan tentang kearifan lokal masyarakat Dayak Hibun di Desa Gunam Dusun Beruak Kecamatan Parindu Kabupaten Sanggau menjadi lebih lengkap.

2. Pedoman wawancara perlu di sempurnakan untuk meningkatkan kualitasdalam penelitian kearifan lokal adat istiadat masyarakat di Desa 
Gunam Dusun Beruak Kecamatan Parindu Kabupaten Sanggau menjadi lebih baik.

3. Perlu didokumentasikan aturanaturan tentang kearifan lokal masyarakat Dayak Hibun sehingga hutan teringkang di Desa Gunam Dusun Beruak Kecamatan Parindu Kabupaten Sanggau tetap terjaga kelestariannya.

DAFTAR PUSTAKA

Agusta, I. (2003). Teknik Pengumpulan dan Analisis Data Kualitatif. Pusat Penelitian Sosial Ekonomi. Litbang Pertanian, Bogor, 27.

Andheska, H. (2018). Kearifan Lokal Masyarakat Minangkabau dalam Ungkapan Kepercayaan Rakyat. Basindo: Jurnal kajian bahasa, sastra Indonesia, dan pembelajarannya, 2(1), 22-28.

Azwir, A., Jalaluddin, J., \& Ibrahim, I. (2017). Peranan Masyarakat Dalam Menjaga Kelestarian Hutan Sebagai Sumber Kehidupan. Jurnal Ekonomi Manajemen dan Akuntansi (JEMSI), 3(1).

Hartono, Y., \& Setiana, D. (2012). Kearifan Lokal Tradisi Uyen Sapi Perajut Integrasi Sosial (Studi Kasus Di Desa Jonggol Kecamatan Jambon Kabupaten Ponorogo). Agastya: Jurnal Sejarah Dan Pembelajarannya, 2(1).

Hasanuddin, W. S. (2015). Kearifan lokal dalam tradisi lisan kepercayaan rakyat ungkapan larangan tentang kehamilan, masa bayi, dan kanak-kanak masyarakat Minangkabau wilayah adat luhak nan tigo. Kembara: Jurnal
Keilmuan Bahasa, Sastra, dan Pengajarannya, 1(2), 198-204.

Nurcahyono, O. H., \& Astutik, D. (2018). Harmonisasi Masyarakat Adat Suku Tengger (Analisis Keberadaan Modal Sosial Pada Proses Harmonisasi Pada Masayarakat Adat Suku Tengger, Desa Tosari, Pasuruan, Jawa Timur). Dialektika Masyarakat: Jurnal Sosiologi, 2(1), 1-12.

Prabowo, H.S., MUI., Tobing, I.S., Abbas, A.S., Saleh, C., Huda, M., Mulyana, T.M. and Mangunjaya, F.M., (2017). Pelestarian Satwa Langka untuk Keseimbangan Ekosistem: Penuntun Sosialisasi Fatwa MUI No 4, 2014, tentang Fatwa Pelestarian Satwa Langka untuk Menjaga Keseimbangan Eksosistem (Vol. 1). LPLH-SDA MUI.

Senoaji, G. (2004). Pemanfaatan Hutan Dan Lingkungan Oleh Masyarakat Baduy Di Banten Selatan (the Uses of Forest and the Environment by Baduy Community in South Banten, Indonesia). Jurnal Manusia dan Lingkungan, 11(3), 143-149.

Sinapoy, M. S. (2018). Kearifan Lokal Masyarakat Adat Suku Moronene dalam Perlindungan dan Pengelolaan Lingkungan Hidup. Halu Oleo Law Review, 2(2), 513-542.

Sufia, R., Sumarmi, S., \& Amirudin, A. (2016). Kearifan Lokal Dalam Melestarikan Lingkungan Hidup (Studi Kasus Masyarakat Adat Desa Kemiren Kecamatan Glagah Kabupaten Banyuwangi). Jurnal Pendidikan: Teori, Penelitian, dan Pengembangan, 1(4), 726-731. 
JURNAL HUTAN LESTARI (2019)

Vol. 7 (4) : 1668 - 1681

Thamrin,H. (2013). Kearifan Lokal dalam

PelestarianLingkungan. Kutubkha nah, 16(1), 46-59.

Yamani, M. (2011). Strategi perlindungan hutan berbasis hukum lokal di enam komunitas adat daerah bengkulu. Jurnal Fakultas Hukum UII, 18(2), 175192.

Yulianto, A. (2019). Kepercayaan Lokal dalam Pemali Banjar did Kalimantan

Selatan. Mabasan, 13(1), 1-13. 